\title{
Utilizing Paper Waste and Dry Leafs as Raw Material to Produce Comboard for Interior Design Application
}

\author{
Firman Hawari ${ }^{1}$, Agus Sachari ${ }^{2}$, and Adhi Nugraha ${ }^{3}$ \\ ${ }^{1,2,3}$ Faculty of Fine Art and Design, Bandung Institute of Technology, Bandung, Indonesia \\ ․ㅏmanhawari@ymail.com, ${ }^{2}$ aasachari@gmail.com, ${ }^{3}$ adhinugrahadesign@gmail.com
}

\begin{abstract}
Focus of this paper is to reduce dependence of interior design and construction activities on wood as natural resources and preserve them from extinction. An implementation is with exploring alternative sources of raw materials that are new, have no impact and are environmental friendly.Beginning, several experimental stages have been carried out by utilizing urban waste: paper waste and dry leafs, to be developed as a raw material.And the type of material chosen to be made: panel.Some reasons are easy treatment of materials, easy achieving shape, easy of environmental adaptation, and influence of design environment.Several production trials have been carried out.From these, a production method that called the 'vertical cross configuration' was born.This advanced experiments can produce a solid, hard and strong prototype panel.It is called 'comboard'.From laboratory test, known that comboard has physical capabilities equivalent to plywood / multiplex that already exists.
\end{abstract}

Keywords: paper waste, dry leafs, configuration of vertical cross method, comboard

\section{INTRODUCTION}

In Indonesia the movement of greenhouse industry was followed up with the creation of \# Green Industry Law by the Ministry of Industry Republic of Indonesia with Republic of Indonesia Law No. 3 of 2014 concerning Industry resources that are managed sustainably are able to align industrial development with preservation of environmental functions so as to provide benefits tocommunity.Some initial experiments were conducted to study and overcome properties of sheet as well as opportunities for arrangement of structure and visualization. Implementation of solid perceptionwhich is the basic of thought in it.A variety of supporting that 'green' materials needs to be also tested.To produce panels from waste paper and dry leafs, this study uses method of vertical cross configuration to form structure solidity and reaching aesthetic value on resulting surface[1].

In this study the problems include:1) Scope of the problem: the ability of basic ingredients of paper waste and dry leafs that are fragile, weak, and fragile to be arranged and combined into panel that a rigid, sturdy, strong, and decent. 2) Research restrictions: the basic ingredients used are paper waste and dry leafs from urban areas,resulting panel has a function as a supporting material for interior planning and building construction activities, resulting panel is also planned to have the same treatment pattern as similar material that already 
existed before, and plan for the production process to be carried out in an environmentally friendly manner. 3) Planned results obtained: know ability of resulting panel is feasible, ecodesign, and can be accounted for functionally and aesthetically, determine visualization of panel surface globally in accordance with its function, plans development activities involving relevant SMEs.

Compared to panels product of wood that have existed before, this panel provides an alternative innovation of materials that were not previously imagined, namely paper waste and dry leafs. Where both materials are arranged through method of ' vertical cross configuration' by utilizing each original characters and appearance[2]. The thermoplastic adhesive is polychloroprene which is easily biodegradable, inexpensive, and easy to obtain. So that resulting panel can be functioned through structure and visuals. Factors that are expected can be reached to support as added value and novelty in implementation of its utilization[3].

\section{METHOD}

In 'Materials and Designs', material development that are more maturity but the value of 'novelty' is agreed upon by combining materials with other materials, or processing them in new ways to make composite or hybrid materials - sandwich structures, dressing systems, multilevel or layered structures.Utilization of old materials in the new order can be seen and new stimulus provides to optimize its potential. For designers, new materials and opportunities. Opportunities are obtained from development technical mindset or aesthetic[4].

This study uses experimental and applicative methods to produce panel shapes in an effort to accommodate understanding of combination of fragile and weak basic ingredients.In an implementation, panel production pattern applies method of vertical cross-configuration in constructing structures to obtain a proper and accountable panel. In a sense the resulting comboard panel has strength and solidity, and is able to build functional products that have aesthetic value.

\section{RESULT AND DISCUSSION}

\subsection{Paper waste and dry leafs}

Waste paper and dry leafs are widely obtained from several areas, such as offices, photocopy businesses, schools, shops, roadside, and others. Some reasons for choosing waste paper and dry leafs are based on several considerations, including: large quantities (which means guaranteed supply), easy to find, sheet-shaped, and strong visual character. So far, paper waste use as a recycled paper is to increase added value and for sustainable handling of inorganic waste. While dry leafs are used as compost to fertilize plants. But for this, its economic added value is very low[5].

\subsection{Process}

Experiments were carried out through panel production from dry leafs and paper waste by using a vertical cross configuration method, which was completed with a laboratory trial application to find a physical solution[6]. The trial data is used as a reference for developing 
panel products as objects of daily function. Experiment process contains several stages, including:

a. Pre-production: Preparation and preparation of production, preparing raw materials and supporting materials, and preparing supporting equipment. Tata Surdia in 'Knowledge of Technical Materials' (1984) published by Pradnya Paramita, Jakarta, p. 229 - 235 said that polymers is defined as a combination of several structural units (monomers) arranged repeatedly and bound by an attractive force called covalent bonds. One example is thermoplastics and that is widely used is polypropylene. This is the adhesive used in this research.

b. Theory, Wucius Wong in his book 'Three Dimensional Design Principles' (1977) states that solid is the path traveled by moving fields (in a direction that is not in the intended direction) makes it solid. And from experiments that can be known vertical sheet position held by power in sustaining compressive power from above. These results provide instructions for optimizing sheets in a vertical position[6].

Vertical ability provides the chance of strength from flat planes produced by gluing together pieces of base material. This is an idea that underlies thinking of application of vertical cross configuration in panel production in this study.

c. Implement a vertical cross configuration method. Specifically, this method is described as a pattern of utilizing vertical ability from arrangement of sheet material that is fragile, thin, and also limp into a strong and sturdy board structure. Structurally, the vertical cross configuration consists of 4 layers, including: 1) Two layers of internal structure: consisting of 2 layers, each made of waste paper sheets that have been finished and arranged vertically. Composing paper layer is supported by polychloroprene adhesives. Both layers that is produced then arranged cross-linked and glued together. 2) Two surface layers: outer layer consists of dry leafs which cover both sides of the inner structure that has been glued together. An arrangement of outer layer is done horizontally. Gluing using polychloroprene adhesives.

Adventages of this structure include panel strength that are very adequate, rigid, and easy to maintain, while weakness say that manufacturing process is very long to do and require accurate and precise capabilities in manufacturing process. A series of internal structures formed from HVS paper, cardboard, and folio types. While outer structure consists of dry leaves. Every pattern of attachment uses polychloroprene,an adhesive type.

In detail, implementation of this method must be neat and measurable. All parts must be cut on required size and every step must be done systematically. That way production process (cutting, preparation and gluing) can provide an expected panel results.From standpoint of production management, this is one of factors of new industry opportunities. It can be said that the presence of waste in urban areas is not a problem but an opportunity that is quite promising in terms of technology and utilization. Correspondingly, implementing vertical cross configuration by utilizing dry leafs and paper is also capable to help save an urban environment.Waste collection and sorting activities can also provide employment opportunities for community to improve their standard of living and assist local governments in managing waste management.

In addition, to support the balance of nature by providing opportunities for tree species in forest to grow and develop as needed to be cut down later, it can also be used eventually. The manufacturing process of 'vertical cross configuration' in this research is as follows below: 


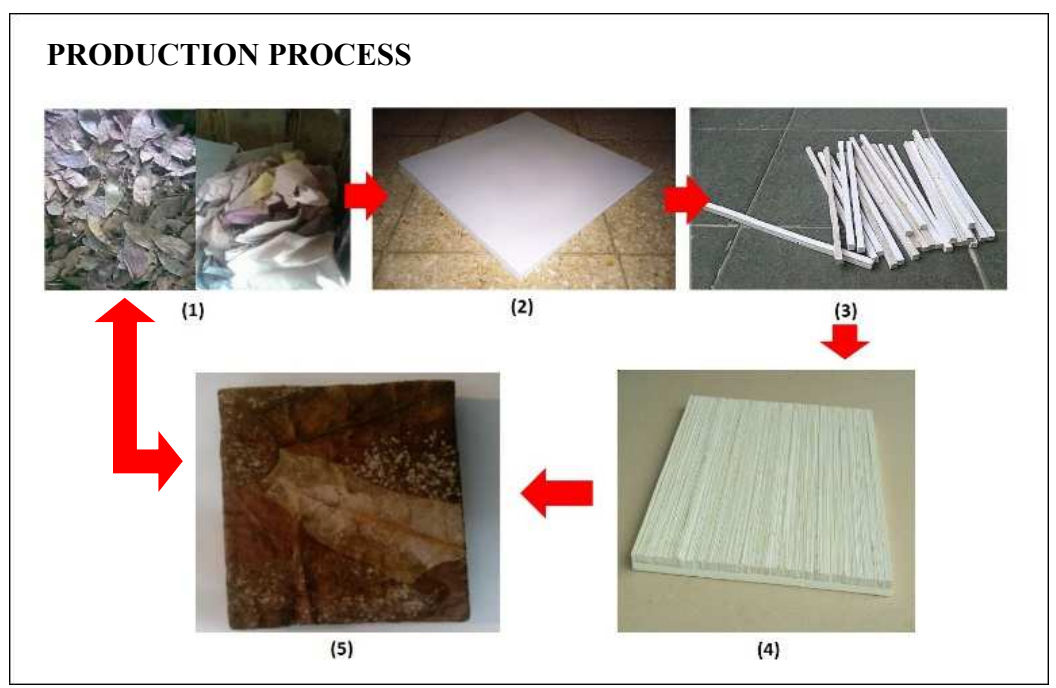

Picture4Production process

Note:

(1) Collecting paper waste and dry leaf as a base material. The materials are then cleaned by wiping

(2) To form an internal structure, waste sheet is arranged horizontally so that it produces a thickness in accordance with panel thickness to be made

(3) Then resulting layer shape is cut into pieces as shown above vertically neatly so that it forms an elongated component

(4) The components are arranged horizontally so that a vertical plane is made horizontally. It takes two fields as for next step. Then the two fields are glued together precisely and neatly.

(5) After being glued together as a whole, each outer surface is given a layer of dry leafs arranged so that it covers the entire horizontal surface. Then it be a comboard.

c. Post-production: testing a compressive and flexural ability conducted in laboratory. Tests are carried out using mechanical equipment with measurements adjusted to ASTM (American Society for Testing and Materials) test standards. Test results in next section.

d. Experiment results are used as a reference for further activities, namely production of functional objects for daily applications (in this study: furniture for residential)

In addition to experimental activities, data collection is also carried out through field observations, interviews, and literature review to observe an application of material technology related to description and type of municipal waste, character of municipal waste, basic form theory, environmentally friendly values, supporting materials, applications a variety of shape configurations, ability standards for interior design materials, panel production processes from dry leafs and paper waste, and also formulation problems.

\subsection{Comboard}


From steps above, it produced a panel called a comboard. Some physical appearance of comboard can be seen as follows:

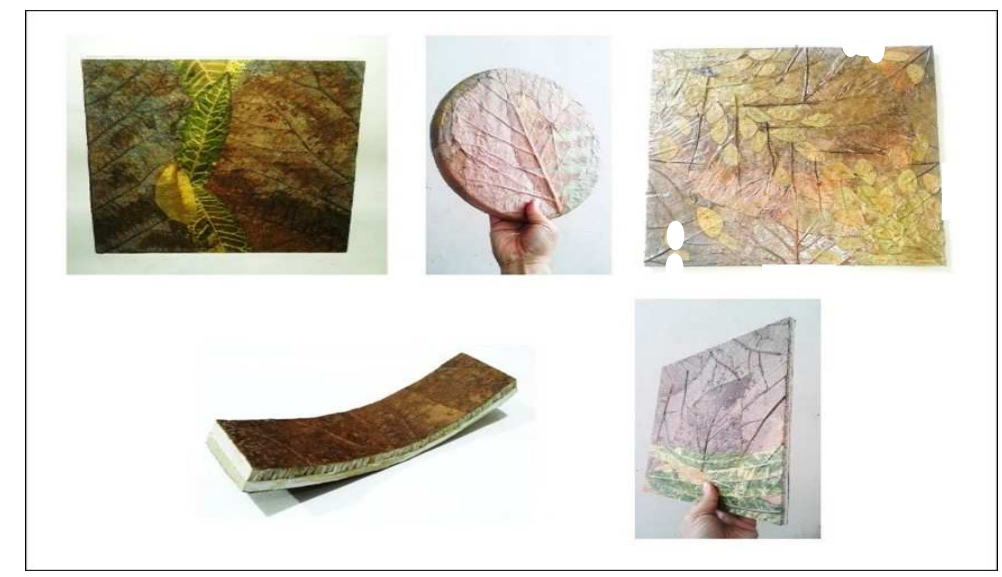

Picture 4 Tvne of comboards

Comboard has a thickness: 12 mmand $22 \mathrm{~mm}$. Smooth character and fabric produced by comboard provide opportunities more elegant characters in interior space planning. Comboardhas 2 types of panel, namely 'common' and 'custom'. The qualifications include: 1) Common:flat comboard similar to pre-existing wood panels. The production process is planned regular. 2) Custom: orders are arranged according to the giver's request. The production process is directed to adjust.

\subsection{Physical test}

Laboratory tests for comboard was carried out in the ITB Structure Engineering Laboratory to find qualifications of compressive tests and arch tests. Standardization of tests in accordance with ASTM (American Society for Testing and Materials). Ability test of a comboard that have been carried out give the following results: Panel with dimensions of width $30.9 \mathrm{~mm}$ and height of $19.9 \mathrm{~mm}$ with a pedestal length of $150 \mathrm{~mm}$ have ability to stand with a load of max. 1,954 tons. While flexural strength of $40.44 \mathrm{~kg} / \mathrm{mm} 2$.Ability test results show the potential of a comboard as a panel product that deserves its function as building material. Not only buildings but also furniture, construction, and other structural facilities[7][8].

\subsection{Application}

Some functional products that are produced made of comboard include: furniture, decorative elements, interior ornaments, interior structures, and so on. Utilization as aesthetic ornaments, structural and functional ornaments[9]. Here are some examples of comboard applications in making furniture:

1. Seating facilities

In this product, some function will be find; seating, keeping and playing. It also various appearance. Sitting facilities have basic dimensions specifications, including: length 50 $\mathrm{cm}$, width $30 \mathrm{~cm}$, height $35 \mathrm{~cm}$, and thickness $22 \mathrm{~mm}$.Picture below will show that. 


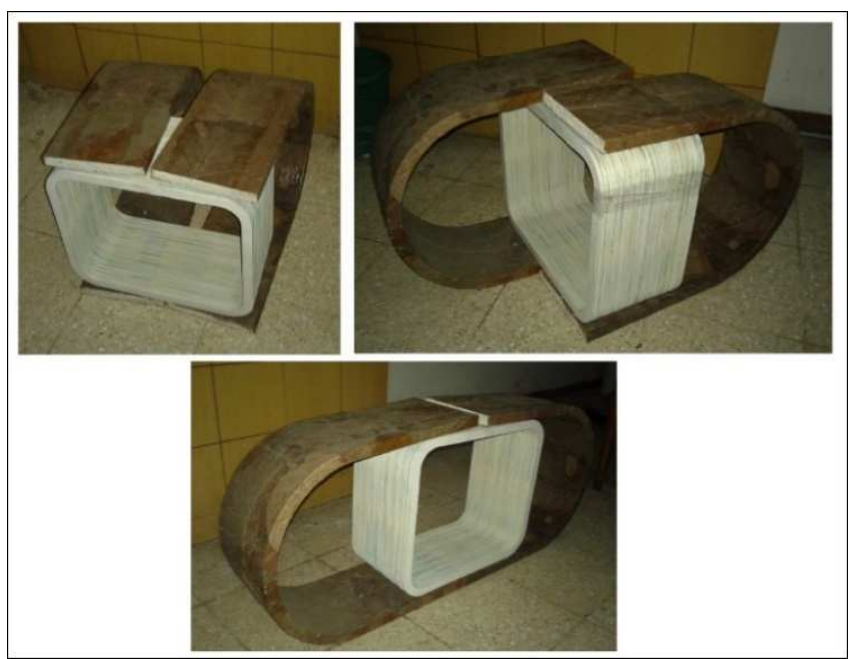

Picture6Seating facility made of comboard (custom)

The resulting product was successfully made as expected. Pattern of changes in form and function are balanced with a good connection system and able to accommodate needs and functions to be supported.Also ability of a comboard that is able to withstand burden and movement there[10][11].

\section{Wall material}

This product is used by attaching it to the wall. A frame as thick as $5 \mathrm{~cm}$ is needed for attaching the creel. That way, the wall appearance will visualized bay natural look. Comboard has detailed specifications, including: length $4 \mathrm{~m}$, width $3 \mathrm{~cm}$, thickness 12 $\mathrm{mm}$, using galvalum frame, adhesive: polychloroprene.Picture below will show that. A panel mounted on the wall provides a natural, warm, and familiar atmosphere of space. The dry leaf pattern created provides a dynamic mindset for space user. Thus, positive results can be expected from using of this space.

\section{CONCLUSION}

From discussion above, several variables that can be raised include: waste paper and dry leafs can be used as a raw material for making structural materials, production process takes a long time to be done manually, machine tools usage is highly recommended, implementing vertical crossconfiguration can develop paper waste and dry leafs that fatty, limp, and brittle sheets into a strong, rigid and aesthetically textured panel structure. Beside that comboard has a decent physical ability and can be accounted for as a raw material for interior design and aesthetic elements such as furniture, decorative, and supporting elements. This research will open opportunities for development of industries creatives and new opportunity for the general public and SMIs. 


\section{REFERENCES}

[1] Agus SAchari. 2014. 'Estetika, Makna Simbol dan Daya'. ITB Publisher. Bandung. Indonesia. 2014.

[2] D.W Junaidy, Y. Nakamori, M. Hirata, and Y. Nagai. 2013. 'Evaluation on Color Fabrics for Comfort in Health Care Interior Facility. Buletin of Japanese Society for the Science of Design, 60(3), 3_49-3_54. Japan

[3] Agnes Dwi Yanti Winoto. 'Ilmu Bahan Bangunan'. Taka Publisher. Gramedia. Indonesia. 2015.

[4] Albert Uchenna Ude, Che Husna Azhari. Lateral crashworthiness response of bombyx mori fibre. 1227-1239 doi: 10.3934/matersci.2019.6.1227 6(6). 2019

[5] Farid Mulana. Iskandar Hisbullah. 'Pembuatan Papan Komposit Dari Plastik Daur Ulang dan Serbuk Kayu serta Jerami Sebagai Filler'. Jurnal Rekayasa Kimia dan Lingkungan. Jurusan Teknik Kimia FakultasTeknik, Vol 8, No 1, ISSN 1412-5064. 17 - 22. Universitas Syiah Kuala Banda Aceh. Indonesia. 2011.

[6] Firman Hawari. 'Kajian Dan Eksperimen Material Dry Leaf Board Sebagai Komponen Fungsi Teknis Dan Estetik Dari Sistem Akustik Ruang'. PNPB - ITS. 1 - 16. Surabaya. Indonesia. 2014.

[7] Ali Hadi Tarkono. 2016. 'Pemanfaatan Limbah Kelapa Sawit Sebagai Material Teknik'. Jurnal Rotor. Teknik Mesin. Fakultas Teknik. Universitas Jember. Vol 9 No 2. ISSN 2460-0385. Jember. Indonesia

[8] Lastri Anita Gultom. Dirhamsyah. Dina Setyawati. 'Sifat Fisik Mekanik Papan Partikel Jerami Padi (Mechanical and physical properties of particle board rice straw)'. Jurnal Hutan Lestari. Universitas Tanjungpura. Vol 1 No 3. p-ISSN 2338-3127. 458 - 465. Pontianak. Indonesia. 2013.

[9] Ummi Qorina. Alimin Mahyudin. Sri Handani. 2016. 'Pengaruh Persentase Massa Gipsum Dan Serat Terhadap Kuat Tekan Dan Kuat Lentur Papan Semen - Gipsum Berserat Eceng Gondok'. Jurnal Fisika. Universitas Andalas. Vol. 5, No. 3, ISSN 2302-8491, Universitas Andalas, Padang, Indonesia, 2016

[10] Yi Yang. Comment on "Powering sustainable development within planetary boundaries" by I. M. Algunaibet, C. Pozo, A. Galán-Martín, M. A. J. Huijbregts, N. Mac Dowell and G. GuillénGosálbez, Energy Environ. Sci., 2019, 12, 1890. Energy Environ. Sci., 2020, Advance Article https://doi.org/10.1039/C9EE01176E. 2019.

[11] Sindung Haryanto. Teori Strukturalisme. Dalam Anatomi dan Perkembangan Ilmu Sosial, Bagong Suyanto dan M Khusna Amal (ed) Aditya Media. Yogyakarta. Indonesia. 2010. 